\title{
Linkage analysis of obesity phenotypes in pre- and post-menopausal women from a United States mid-western population
}

\author{
Linda E Kelemen ${ }^{1 *}$, Elizabeth J Atkinson ${ }^{2}$, Mariza de Andrade ${ }^{2}$, V Shane Pankratz ${ }^{2}$, Julie M Cunningham³, \\ Alice Wang ${ }^{2}$, Christopher A Hilker ${ }^{3}$, Fergus J Couch ${ }^{3}$, Thomas A Sellers ${ }^{4}$, Celine M Vachon ${ }^{2}$
}

\begin{abstract}
Background: Obesity has a strong genetic influence, with some variants showing stronger associations among women than men. Women are also more likely to distribute weight in the abdomen following menopause. We investigated whether genetic loci link with obesity-related phenotypes differently by menopausal status.

Methods: We performed univariate and bivariate linkage analysis for the phenotypes of body mass index (BMI), waist $(\mathrm{W})$ and hip $(\mathrm{H})$ circumferences $(\mathrm{WC}, \mathrm{HC})$, and WH ratio (WHR) separately among 172 pre-menopausal and 405 post-menopausal women from 90 multigenerational families using a genome scan with 403 microsatellite markers. Bivariate analysis used pair-wise combinations of obesity phenotypes to detect linkage at loci with pleiotropic effects for genetically correlated traits. BMI was adjusted in models of WC, HC and WHR.

Results: Pre-menopausal women, compared to post-menopausal women, had higher heritability for BMI $\left(h^{2}=94 \%\right.$ versus $h^{2}=39 \%$, respectively) and for $\mathrm{HC}\left(h^{2}=99 \%\right.$ versus $h^{2}=43 \%$, respectively), and lower heritability for WC $\left(h^{2}=29 \%\right.$ versus $h^{2}=61 \%$, respectively) and for WHR ( $h^{2}=39 \%$ versus $h^{2}=57 \%$, respectively). Among premenopausal women, the strongest evidence for linkage was for the combination of BMl and HC traits at 3 p26 (bivariate LOD = 3.65) and at 13q13-q14 (bivariate LOD = 3.59). Among post-menopausal women, the highest level of evidence for genetic linkage was for $\mathrm{HC}$ at 4p15.3 (univariate LOD = 2.70) and 14q13 (univariate LOD = 2.51). WC was not clearly linked to any locus.

Conclusions: These results support a genetic basis for fat deposition that differs by menopausal status, and suggest that the same loci encode genes that influence general obesity (BMI) and HC, specifically, among premenopausal women. However, lower heritability among pre-menopausal women for WC and WHR suggests that pre-menopausal waist girth may be influenced to a greater extent by controllable environmental factors than postmenopausal waist girth. Possibly, targeted interventions for weight control among pre-menopausal women may prevent or attenuate post-menopausal abdominal weight deposition.
\end{abstract}

\section{Background}

Over the past 25 years, the prevalence of overweight adults increased by $40 \%$ and that of obese adults by almost 2-fold in the United States [1]. Together, overweight and obese adults account for $68 \%$ of Americans [2]. Global increases in weight gain have also been reported [3], and mirror the rise in obesity-related

\footnotetext{
* Correspondence: Ikelemen@post.harvard.edu

'Department of Population Health Research, Alberta Health Services-Cancer Care, Calgary, AB, Canada

Full list of author information is available at the end of the article
}

chronic diseases including type 2 diabetes, cardiovascular diseases [4], and several cancers [5].

The rapid increases in overweight and obesity are multi-factorial and only partly attributable to changes in lifestyle practices [4]. Results from transgenic and crossbred animal models and population-based studies (reviewed in [6]), and more recently genome-wide association studies (GWAS) [7-14], provide strong evidence for genetic influences on obesity-related phenotypes, including overall weight gain and body fat distribution. Although family and twin studies estimate that $40-70 \%$

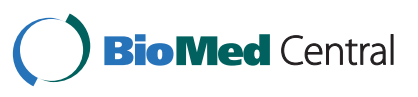


of the population variation in body mass index (BMI), a measure of overall adiposity, is due to genetic factors $[15,16]$, genetic variants identified from the GWAS account for $<1 \%$ of the variance of BMI in those subjects $[12,13]$, leaving a large proportion of the genetic variation unexplained.

Body fat distribution may be more important than overall adiposity on health [17]. Visceral abdominal fat composed of omental and mesenteric adipocytes is more metabolically active than subcutaneous fat [18], secreting a variety of cytokines and inflammatory agents with immunological, vascular, and metabolic actions [19]. Previous studies showed that health risks are positively associated with waist circumference but inversely related to hip circumference after adjustment for potential confounders [20,21]. Body composition changes occur frequently among women following menopause, in whom age-related increases in obesity occur more often [22]. Observations based on objective assessments of body composition such as CT scans noted increased visceral fat deposition in post-menopausal compared to pre-menopausal women [23]. Changes in body fat distribution during the menopausal transition have also been demonstrated longitudinally [24,25], including an absolute cumulative 6-year increase of approximately $5.7 \mathrm{~cm}$ in waist circumference [24]. Estrogen treatment has been shown to prevent the increase in intra-abdominal fat $[26,27]$. Possibly, the genetic determinants of abdominal fat deposition and its metabolic sequelae may differ from those that determine hip deposition of fat.

To our knowledge, no studies have examined genetic determinants of obesity among pre-menopausal and post-menopausal women separately. Because these groups appear to have different propensities for fat deposition, we used linkage analysis to test the hypothesis that obesity-related phenotypes are influenced by different genetic loci among pre-menopausal and postmenopausal women using data from the Minnesota Breast Cancer Family Study.

\section{Methods}

\section{Study Population}

The study was approved by the Institutional Review Boards at the University of Minnesota and Mayo Clinic and informed written consent was obtained from all participants. Details of the study design and methods have been published [28]. Briefly, breast cancer probands $(n=544)$ were ascertained at the Tumor Clinic of the University of Minnesota Hospital in 1944. A follow-up study was initiated in 1990 and telephone interviews detailed four-generation pedigrees of the probands and eligible sisters, daughters, nieces and granddaughters of the probands and women identified as the spouse of corresponding male first- and second-degree relatives of the probands. Interviews were attempted with 6,664 living female relatives 18 years of age (426 of the 544 families), and 6,194 (93\% response) consented.

\section{Questionnaire Data}

The telephone interview collected information on history of cancer, weight history, marital status, education, occupational class, medical history, reproductive history, oral contraceptive use, physical activity and history of smoking and alcohol intake. Menopausal status was determined from the response to a question of whether the participant had a menstrual period within the last year, excluding those brought on by hormones. Subjects were mailed a body measurement questionnaire that asked for replicated measures of current height and weight. Circumferences of the waist ( 2 inches above the umbilicus) and hips (maximal protrusion) were also obtained using a validated protocol [29].

\section{Subject Inclusion}

The present study sample includes self-reported Caucasian women from 90 of 426 families with the most informative pedigrees chosen from simulation analysis, excluding the probands with breast cancer [28]. After the exclusion of 13 individuals due to consistent Mendelian errors across all markers, 889 individuals (756 women and 133 men) for whom we had blood-based DNA formed the basis of the genome screen. Males were excluded from analyses, although their genotypes were used in linkage analyses for determination of identity by descent (IBD) and to infer genotypes on female family members with missing DNA. The final sample consisted of 577 women who completed the telephone interview, returned the body measurement questionnaire and provided a DNA sample.

\section{Genotyping}

DNA was genotyped for 403 microsatellite markers across the genome in the Mayo Clinic Cancer Center's Genotyping Shared Resource according to conditions suggested in the ABI Prism Linkage Mapping Set (PE Applied Biosystems, version 2.5, Foster City, CA). Genotypes were scored using an ABI 3100 or ABI 3730 DNA sequencer and ABI Genotyper v3.7 or ABI Genemapper v3.5 software. The average heterozygosity per marker was 0.77 and the average inter-marker distance was 8.9 cM. Of 361,021 called genotypes, 357,172 (98.9\%) were Mendelian-consistent and used in analysis.

\section{Statistical analysis}

To satisfy the normality assumptions required by variance components linkage analysis, we applied the $\mathrm{t}$-rank transformation to the distributions of waist and hip circumferences and BMI; WHR was left 
untransformed. The relation between non-genetic covariates with known or suspected influence on obesity phenotypes [30] were examined separately by menopausal status using univariate regression and backward elimination regression models with retention $P$ values < 0.10 (SAS Institute, Cary, NC); both approaches identified similar non-genetic covariates for the final models. We adjusted for age (continuous), parity $(0,1-2$, or $>2$ births), education (less than high school, some college, or college graduate), smoking (never, former smoker with $<20$ pack years, former smoker with $\geq 20$ pack years, current smoker with $<20$ pack years, or current smokers with $\geq 20$ pack years), physical activity (low, moderate, or high), and oophorectomy (no, one ovary or both removed). Since BMI is a measure of overall obesity, it was included in the models of waist or hip circumference and WHR to better isolate the genetic influences on body fat deposition in the waist and hip areas. BMI was defined in $\mathrm{kg} / \mathrm{m}^{2}$. Because BMI was not normally distributed, we included the inverse (1/BMI) in continuous format in statistical models.

Multipoint IBD sharing probabilities were estimated in SIMWALK2 [31]. Heritability between the transformed and covariate-adjusted trait values was estimated with variance decomposition using maximum likelihood methods [32]. Univariate variance components linkage analysis was performed using the R library MULTIC $[33,34]$ and a Fisher scoring algorithm to estimate genetic parameters while also adjusting for covariates. Genotype information at a locus was characterized by the probability that two related individuals share none, one, or two alleles IBD. Linkage was tested by a likelihood ratio test for the hypothesis that the QTL variance component is equal to zero compared with it being greater than zero [35]. The data were analyzed using no ascertainment correction because the phenotypes of interest did not lead to the ascertainment of the families. Univariate logarithm of odds (LOD) scores $\geq$ 2.0 were considered suggestive and LOD scores $\geq 3.3$ were considered significant [36].

Multivariate variance component analyses have been shown to improve power to detect linkage over univariate procedures at loci with pleiotropic effects for genetically correlated phenotypes [37]. Evidence to support pleiotropy for obesity-related phenotypes in the current analysis includes the strong association at LYPLAL1 among women for both BMI and WHR [14]. We, therefore, performed bivariate linkage analyses using pair-wise combinations of obesity-related traits. Due to the greater degrees of freedom, higher LOD score thresholds are required to achieve comparable levels of statistical significance (e.g., $\geq 3.0$ was considered suggestive and those $\geq$ 4.0 were considered significant) [36]. We performed multiple univariate and bivariate linkage analyses (these are multiple phenotypes and should not be confused with multiple testing). The LOD scores and corresponding $P$ values serve chiefly to indicate the relative strength of evidence in favor of linkage. Similarly, when the bivariate LOD scores met the bivariate LOD score criteria for linkage, strength of the evidence in favor of pleiotropy was inferred if the bivariate $P$ value was as small as or smaller than the component univariate $P$ values.

\section{Results}

Post-menopausal women were older, heavier and had greater waist circumference than pre-menopausal women, although no substantial difference was noted in hip circumference (Table 1). Among post-menopausal women, current users of hormones were, on average, younger ( 59.2 years, $\mathrm{n}=138)$ than never ( 65.6 years, $\mathrm{n}$ $=193$ ) or former (66.3 years, $\mathrm{n}=74)$ hormone users. In age-adjusted analyses, current hormone users did not have significantly different WHR $(P=0.10)$, BMI $(P=$ $0.13)$, and waist $(P=0.09)$ or hip $(P=0.25)$ circumferences than former or never hormone users (data not shown). Heritability of obesity traits was significantly greater than $0(P<0.001)$ for all estimates except waist circumference $(P=0.11)$ and WHR $(P=0.05)$ among pre-menopausal women (Table 2 ), suggesting most of the variation observed in these two phenotypes among pre-menopausal women is due to environmental and not genetic influences. Pre-menopausal women compared to post-menopausal women had higher heritability for BMI $\left(h^{2}=94 \%\right.$ versus $h^{2}=39 \%$, respectively) and for hip circumference $\left(h^{2}=99 \%\right.$ versus $h^{2}=43 \%$, respectively), and lower heritability for waist circumference $\left(h^{2}=29 \%\right.$ versus $h^{2}=61 \%$, respectively) and for WHR ( $h^{2}=39 \%$ versus $h^{2}=57 \%$, respectively). The high heritability of $99 \%$ for hip circumference among pre-menopausal women is likely an upper bound estimate. To verify this, we re-ran the hip circumference model among pre-menopausal women without any adjustment for covariates and observed $h^{2}=83 \%$ (standard error $=0.11$; data not shown). This indicates that hip circumference has a very strong polygenic heritability in pre-menopausal women.

For the BMI phenotype, the highest level of evidence for genetic linkage was achieved on chromosomes $2 \mathrm{p} 21$ p22 and 3p26 among pre-menopausal women, based on LOD scores satisfying suggestive evidence (e.g., LOD = 2.89 and 2.90, respectively) (Table 3 and Figure 1). For the hip circumference trait, the highest level of evidence for genetic linkage was achieved on chromosome 13q13 among pre-menopausal women $(\mathrm{LOD}=2.87)$ and on chromosome 4p15.3 among post-menopausal women $($ LOD $=2.70)($ Table 3 and Figure 2$)$. The WHR trait also showed suggestive evidence for linkage among premenopausal women on chromosome 1q21 (Table 3). 
Table 1 Descriptive characteristics among women in the Minnesota Family Study

\begin{tabular}{lll}
\hline Variable $^{\mathbf{a}}$ & Pre-menopausal women $(\mathbf{n}=\mathbf{1 7 2})$ & Post-menopausal women $(\mathbf{n}=\mathbf{4 0 5})$ \\
\hline Age, years & $42(36-47)$ & $63(57-70)$ \\
\hline $\mathrm{BMI}^{\mathrm{b}}, \mathrm{kg} / \mathrm{m}^{2}$ & $24.8(21.9-29.3)$ & $25.6(23.1-29.1)$ \\
\hline $\mathrm{WHR}^{\mathrm{c}}$ & $0.79(0.75-0.84)$ & $0.85(0.79-0.89)$ \\
\hline Waist circumference, inches & $31.0(28.4-35.7)$ & $34.0(30.7-38.0)$ \\
\hline Hip circumference, inches & $39.7(37.1-43.0)$ & $40.0(38.0-43.0)$ \\
\hline
\end{tabular}

${ }^{a}$ Median (25th and 75th percentiles).

${ }^{\mathrm{b}}$ Body mass index.

'Waist to hip ratio.

The bivariate linkage analyses provided suggestive evidence (LOD $\geq 3.0$ ) for 12 loci with pleiotropic effects on pairwise combinations of obesity traits (Table 4). The strongest evidence was among pre-menopausal women on chromosomes 3 and 13, where the bivariate LOD scores for the combination of BMI and hip circumference traits were 3.65 at 3 p26 and 3.59 at 13q13-q14 (Figure 3A and 3B). The bivariate genetic correlations between these two traits were 0.85 at $3 \mathrm{p} 26$ and 0.53 at 13q13-q14 (data not shown). Among post-menopausal women, there was no evidence of loci with pleiotropic effects as indicated by LOD scores $\geq 3.00$ on pairwise combinations of obesity traits.

\section{Discussion}

Over 250 QTL for human obesity-related phenotypes have been published from over 61 genome-wide scans [6] and from over 10 GWAS http://www.genome.gov/ GWAStudies. Only a minority of these, however, examined WHR, waist circumference or hip circumference phenotypes $[9,14,38]$ and, to our knowledge, none published on the genetic regulation of fat deposition in women by menopausal status.

Early observations reported increased visceral fat in post-menopausal compared to pre-menopausal women independent of age using objective assessments of body composition such as CT scans [23]. Samaras and colleagues [39] measured total and central fat using dualenergy X-ray absorptiometry (DEXA) among 216 post-menopausal twin pairs. They reported heritability estimates of $56 \%$ for total fat and $64 \%$ for central fat that did not appear to be explained by the same genetic factors, suggesting the two traits are regulated independently. Pre-menopausal women were not studied. We report similar heritability estimates among post-menopausal women in our study for waist circumference $\left(h^{2}\right.$ $=61 \%$ ) and provide additional evidence that heritability for this trait is lower, and not statistically significant, among pre-menopausal women $\left(h^{2}=29 \%\right)$. These observations support two conclusions. First, low heritability for waist circumference (and for WHR) among pre-menopausal women suggests most of the phenotypic variance is due to environmental influences. Second, the higher heritability for these two phenotypes among post-menopausal women suggests additive genetic factors explain a significantly larger proportion of the inter-individual variation. If true, then interventions that modify environmental contributions to abdominal fat distribution (e.g., increased physical activity, decreased total energy consumption) should target women in their pre-menopausal years, when such interventions may be more effective.

The heritability for hip circumference among premenopausal women $\left(h^{2}=99 \%\right)$ is much larger than among post-menopausal women $\left(h^{2}=43 \%\right)$. Along with higher heritability for hip circumference among premenopausal women, we also found suggestive evidence for linkage. We showed that the phenotypes of BMI and hip circumference were linked to the same loci at chromosome 2p21-p22, chromosome 3p26, and chromosome 13q13-q14. The high genetic correlation between these traits and their linkage to the same chromosomal

Table 2 Heritability estimates ${ }^{a}$ for obesity-related traits among women in the Minnesota Family Study

\begin{tabular}{lcc}
\hline Obesity $_{\text {trait }}{ }^{\mathbf{b}}$ & Pre-menopausal women $(\mathbf{n}=\mathbf{1 7 2})$ & Post-menopausal women $(\mathbf{n}=\mathbf{4 0 5})$ \\
\hline BMI & 0.94 & 0.39 \\
\hline WHR & 0.38 & 0.57 \\
\hline Waist circumference & 0.29 & 0.61 \\
\hline Hip circumference & 0.99 & 0.43 \\
\hline
\end{tabular}

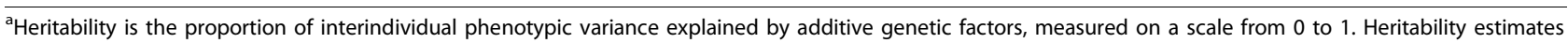
were significantly greater than $0(P<0.001)$ except waist circumference $(P=0.11)$ and WHR $(P=0.05)$ among pre-menopausal women. Obesity traits were adjusted for age, parity, education, smoking, physical activity, and oophorectomy. BMI was not adjusted in model estimates of heritability.

${ }^{\mathrm{b}} \mathrm{BMI}$, body mass index; WHR, waist to hip ratio. 


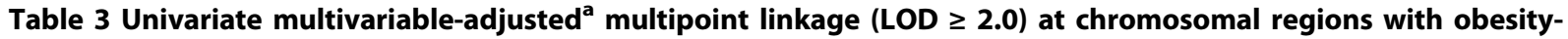
related traits

\begin{tabular}{|c|c|c|c|c|c|c|c|c|c|c|c|c|}
\hline Sample & Position & Trait $^{b}$ & $\begin{array}{l}\text { Peak } \\
\text { LOD } \\
\text { score }\end{array}$ & $\begin{array}{l}\text { Marker } \\
\text { closest } \\
\text { to peak } \\
\text { LOD } \\
\text { score }\end{array}$ & $\begin{array}{l}\text { Genetic } \\
\text { map } \\
\text { distance } \\
\text { of } \\
\text { marker } \\
(\mathrm{cM})^{c}\end{array}$ & $\begin{array}{l}\text { Physical } \\
\text { map } \\
\text { position } \\
\text { of marker } \\
\text { (bp) }{ }^{d}\end{array}$ & 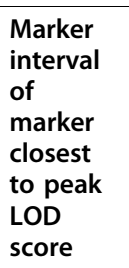 & $\begin{array}{l}\text { Physical } \\
\text { map } \\
\text { position of } \\
\text { marker } \\
\text { interval } \\
(\text { bp })^{d}\end{array}$ & $\begin{array}{l}\text { Nearest } \\
\text { gene on } \\
\text { genome } \\
\text { to } \\
\text { marker }\end{array}$ & $\begin{array}{l}\text { Physical } \\
\text { map } \\
\text { position } \\
\text { of nearest } \\
\text { gene on } \\
\text { genome } \\
\text { (bp) }\end{array}$ & $\begin{array}{l}\text { Nearest } \\
\text { gene } \\
\text { previously } \\
\text { reported } \\
\text { with trait }\end{array}$ & $\begin{array}{l}\text { Physical } \\
\text { position of } \\
\text { nearest } \\
\text { gene } \\
\text { previously } \\
\text { reported } \\
\text { with trait } \\
(\text { bp) }\end{array}$ \\
\hline \multirow[t]{8}{*}{$\begin{array}{l}\text { Pre- } \\
\text { menopausal }\end{array}$} & $1 q 21$ & WHR & 2.09 & D1S498 & 143.75 & $149,568,120$ & $\begin{array}{l}\text { D1S252- } \\
\text { D1S484 }\end{array}$ & $\begin{array}{l}117,358,294- \\
159,034,332\end{array}$ & PIAKB & $149,531,037$ & LYPLALI $^{e}$ & $217,413,846$ \\
\hline & & & & & & & & & & & RASAL2 ${ }^{e}$ & $176,330,253$ \\
\hline & $\begin{array}{l}\text { p21- } \\
\text { p22 }\end{array}$ & BMI & 2.89 & D2S2259 & 68.78 & $42,850,051$ & $\begin{array}{l}\text { D2S367- } \\
\text { D2S391 }\end{array}$ & $\begin{array}{l}34,294,652- \\
46,265,269\end{array}$ & HAAO & $42,847,734$ & TMEM18 ${ }^{e}$ & 657,975 \\
\hline & $3 p 26$ & BMI & 2.90 & D3S1297 & 14.83 & $2,013,403$ & $\begin{array}{l}\text { D3S1297- } \\
\text { D3S1304 }\end{array}$ & $\begin{array}{l}2,013,403- \\
6,894,583\end{array}$ & CNTN4 & $2,117,247$ & $\begin{array}{l}\text { GHRL }^{f} \\
\text { PPARG }^{f}\end{array}$ & $\begin{array}{l}10,302,434 \\
12,304,349\end{array}$ \\
\hline & $3 p 26$ & BMl & 2.90 & D3S1304 & 14.83 & $6,894,242$ & $\begin{array}{l}\text { D3S1297- } \\
\text { D3S1263 }\end{array}$ & $\begin{array}{l}2,013,403- \\
11,492,535\end{array}$ & GRM7 & $6,877,927$ & $\begin{array}{l}\text { GHRL }^{f} \\
\text { PPARG }\end{array}$ & $\begin{array}{l}10,302,434 \\
12,304,349\end{array}$ \\
\hline & $13 q 13$ & $\mathrm{HC}$ & 2.87 & D13S218 & 34.15 & $37,930,231$ & $\begin{array}{l}\text { D3S2338- } \\
\text { D3S1266 }\end{array}$ & $\begin{array}{l}16,824,399- \\
27,932,698\end{array}$ & UFM1 & $37,822,018$ & HTR2A $^{f}$ & $46,305,514$ \\
\hline & $13 q 14$ & BMI & 2.60 & D13S263 & 44.42 & $40,978,920$ & $\begin{array}{l}\text { D13S218- } \\
\text { D13S153 }\end{array}$ & $\begin{array}{l}37,930,231- \\
47,789,009\end{array}$ & $\begin{array}{l}\text { C13orf15 } \\
\text { (RGC32) }\end{array}$ & $40,929,712$ & HTR2A $^{f}$ & $46,305,514$ \\
\hline & $13 q 14$ & BMl & 2.60 & D13S153 & 44.42 & $47,788,735$ & $\begin{array}{l}\text { D13S263- } \\
\text { D13S156 }\end{array}$ & $\begin{array}{l}40,978,920- \\
73,555,776\end{array}$ & $R B 1$ & $47,775,884$ & HTR2A $^{f}$ & $46,305,514$ \\
\hline \multirow[t]{4}{*}{$\begin{array}{l}\text { Post- } \\
\text { menopausal }\end{array}$} & $4 p 15.3$ & $\mathrm{HC}$ & 2.70 & D4S403 & 25.0 & $13,359,926$ & $\begin{array}{l}\text { D4S2935- } \\
\text { D4S419 }\end{array}$ & $\begin{array}{l}6,611,782- \\
18,458,207\end{array}$ & BOD1L & $13,179,464$ & GNPDA2 ${ }^{e}$ & $44,398,926$ \\
\hline & $5 q 21$ & $\mathrm{HC}$ & 2.01 & D5S433 & 115.1 & $103,990,522$ & $\begin{array}{l}\text { D5S644- } \\
\text { D5S2027 }\end{array}$ & $\begin{array}{l}95,838,450- \\
111,173,613\end{array}$ & None ${ }^{g}$ & & $\begin{array}{l}\text { CARTPT }^{f} \\
\text { NR3C1 }^{f} \\
\text { ADRB2 }^{f}\end{array}$ & $\begin{array}{l}71,050,750 \\
142,637,689 \\
148,186,349\end{array}$ \\
\hline & $5 q 22$ & $\mathrm{HC}$ & 2.01 & D5S2027 & 115.1 & $111,173,318$ & $\begin{array}{l}\text { D5S433- } \\
\text { D5S471 }\end{array}$ & $\begin{array}{l}103,990,522- \\
119,077,177\end{array}$ & STARD4 & $110,861,921$ & $\begin{array}{l}\text { CARTPT }^{f} \\
\text { NR3C1 }^{f} \\
\text { ADRB2 }^{f}\end{array}$ & $\begin{array}{l}71,050,750 \\
142,637,689 \\
148,186,349 \\
\end{array}$ \\
\hline & $14 q 13$ & $\mathrm{HC}$ & 2.51 & D14S70 & 34.15 & $33,528,945$ & $\begin{array}{l}\text { D14S275- } \\
\text { D14S288 }\end{array}$ & $\begin{array}{l}25,766,613- \\
43,171,795\end{array}$ & EGLN3 & $33,463,174$ & $E S R 2^{f}$ & $30,234,561$ \\
\hline
\end{tabular}

\footnotetext{
${ }^{a}$ Adjusted for age, parity, education, smoking, physical activity, and oophorectomy. BMI was included in the models of waist circumference and WHR, and of hip circumference and WHR.

${ }^{\mathrm{b}} \mathrm{BMI}$, body mass index; WHR, waist to hip ratio; $\mathrm{HC}$, hip circumference.

'Genetic map distance in centimorgans (cM) is the position of genetic markers relative to each other along a chromosome in terms of recombination frequency, rather than as specific physical distance. One $\mathrm{cM}$ represents approximately $1 \%$ recombination frequency. The greater the recombination frequency between two genetic markers along a chromosome, the farther apart physically they are assumed to be.

dHapMap Genome Browser, NCBI Build 36.

${ }^{\mathrm{e}}$ From genome-wide association studies.

${ }^{f}$ From linkage studies.

${ }^{9}$ None within $500 \mathrm{~kb}$.
}

regions at 3p26 and 13q13-q14 provides evidence for pleiotropic effects of these loci among pre-menopausal women. Because BMI is a ratio measure of weight and height, we cannot rule out that some of the linkage at regions $2 \mathrm{p} 22-2 \mathrm{p} 23$ and $13 \mathrm{q} 14$ is with the height phenotype, as reported by several GWAS of height http://
www.genome.gov/GWAStudies. In contrast, there was no evidence for pleiotropy among post-menopausal women; however, the hip circumference trait showed evidence of linkage to chromosome 4p15.3 and chromosome $14 \mathrm{q} 13$ indicating the influence of independent loci. Although we found higher heritability for waist 


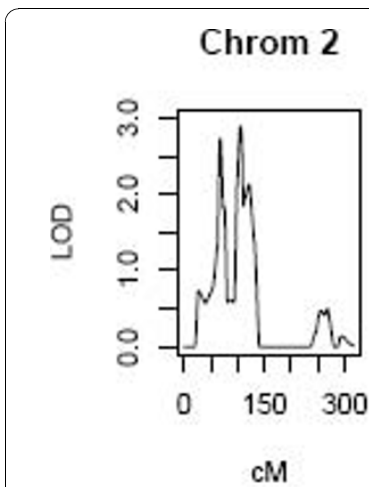

$\operatorname{Max} L O D=2.89$

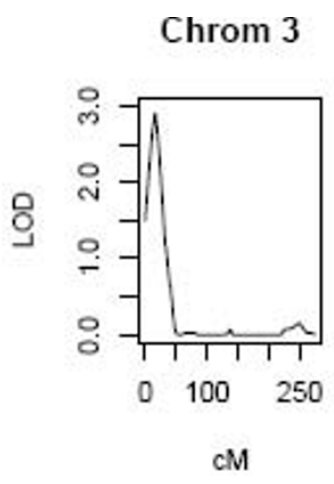

$\operatorname{Max} L O D=2.90$
Figure 1 Maximum LOD scores achieved for univariate linkage to the BMI trait among pre-menopausal women.

circumference among post-menopausal women compared to pre-menopausal women, we did not find evidence for linkage with waist circumference at loci in either of the two groups of women. Reasons for this might include allelic effects that are smaller or causal alleles that are too rare to detect with the given sample size [40], or confounding by unaccounted environmental influences. For instance, if the resemblance of firstdegree family members is partly due to common environmental effects, then an estimate of heritability that is based on their resemblance will be biased upwards [41]. However, our heritability estimate for waist circumference among post-menopausal women was similar to that reported by Samaras and colleagues [39], and the circumferences in this analysis were based on actual measurements that have been shown to be obtained reliably and with good precision [29].

To our knowledge, only two GWAS reported obesity phenotype associations separately by gender. Lindgren

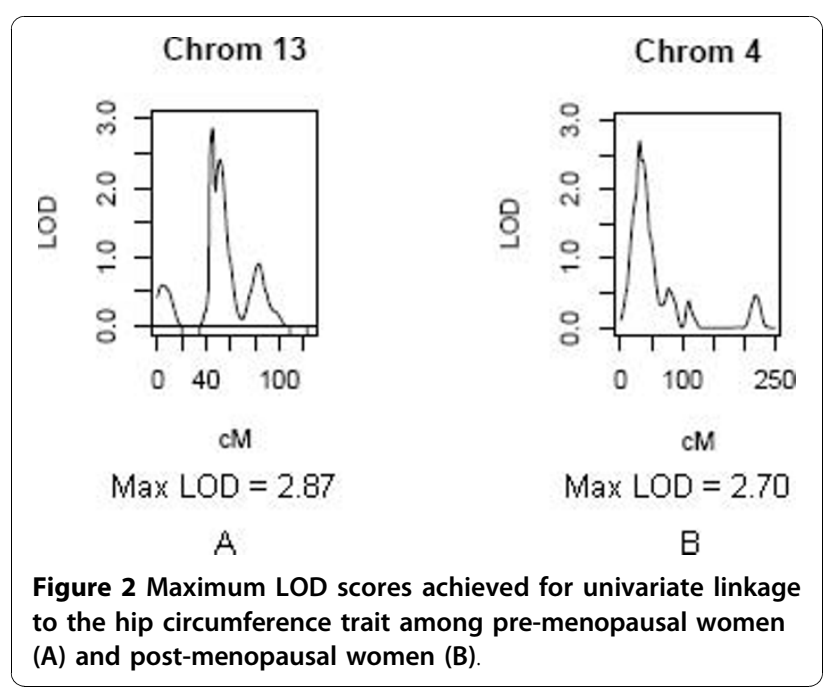

Table 4 Bivariate multivariable-adjusted ${ }^{a}$ multipoint linkage (LOD $\geq 3.0$ ) at chromosomal regions with obesity-related traits among pre-menopausal women.

\begin{tabular}{lllll}
\hline Position & Trait $^{\text {b }}$ & $\begin{array}{l}\text { Peak LOD } \\
\text { score }\end{array}$ & Marker & $\begin{array}{l}\text { Peak LOD position } \\
\text { (cM) }\end{array}$ \\
\hline 2p23 & BMl-HC & 3.30 & D2S165 & 47.90 \\
\hline $2 \mathrm{p} 23$ & $\begin{array}{l}\text { BMl- } \\
\text { WHR }\end{array}$ & 3.17 & D2S165 & 48.47 \\
& & &
\end{tabular}

\begin{tabular}{lllll}
\hline $3 p 26$ & BMI-HC & 3.65 & D3S1304 & 14.05 \\
\hline $3 p 26$ & BMI-WC & 3.00 & D3S1304 & 14.83 \\
\hline
\end{tabular}

\begin{tabular}{lllll}
\hline $11 q 22$ & BMI-HC & 3.14 & D11S898 & 104.45
\end{tabular}

\begin{tabular}{lllll}
\hline $13 q 13$ & BMI-HC & 3.59 & D13S218 & 40.88 \\
\hline $13 q 13$ & HC-WHR & 3.01 & D13S218 & 41.47 \\
\hline
\end{tabular}

\begin{tabular}{lllll}
\hline $13 q 14$ & BMI-HC & 3.59 & D13S263 & 40.88 \\
\hline $13 q 14$ & HC-WHR & 3.01 & D13S263 & 41.47 \\
\hline $13 q 14$ & $\begin{array}{l}\text { WC- } \\
\text { WHR }\end{array}$ & 3.00 & D13S263 & 42.66 \\
\hline $13 q 14$ & $\begin{array}{l}\text { BMl- } \\
\text { WHR }\end{array}$ & 3.28 & D13S263 & 43.25 \\
& & & \\
\hline
\end{tabular}

${ }^{a}$ Adjusted for age, parity, education, smoking, physical activity, and oophorectomy. BMI was included in the models of waist circumference and WHR, and of hip circumference and WHR.

bBMI, body mass index; WHR, waist to hip ratio; WC, waist circumference; HC, hip circumference.

and colleagues [14] reported genome-wide significant associations with WHR near LYPLAL1 at 1q41 among women before adjusting for BMI $\left(\mathrm{P}=2.6 \times 10^{-8}\right)$, which attenuated following BMI adjustment $\left(\mathrm{P}=4.3 \times 10^{-6}\right)$, whereas the association among males was not statistically significant $(P=0.50)$. Associations were also seen for BMI $\left(\mathrm{P}=1.9 \times 10^{-4}\right)$ and waist circumference $(\mathrm{P}=$ $0.01)$ at these loci among women but not for men [14]. The second GWAS reported associations with waist circumference for NRXN3 at 14q31 among women $(\mathrm{P}=$ $0.0005)$ and men $(P=0.001)$, which was no longer statistically significant following BMI adjustment [38]. These studies provide evidence that genetic determinants of adiposity vary by sex, and support further investigation of the GWAS candidates by menopausal status.

Genes previously-reported to be associated with obesity and that reside within marker intervals at our peak LOD scores include GHRL, PPARG, HTR2A and ESR2 (Table $3)$. They influence appetite and the pathology of numerous diseases including obesity [24,42-46]. Sowers and colleagues $[24,42]$ reported findings that suggest changes in ghrelin concentrations in the peri-menopause may precede increases in waist circumference. Ghrelin can stimulate feeding and body weight gain by neuroendocrine 


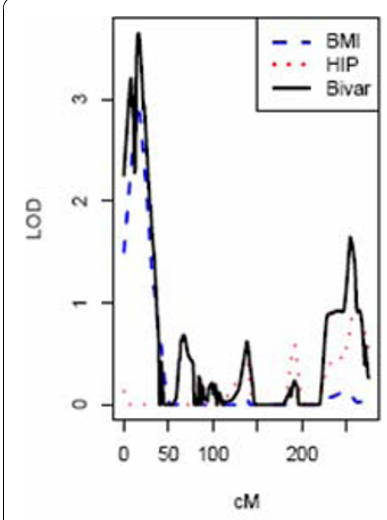

A

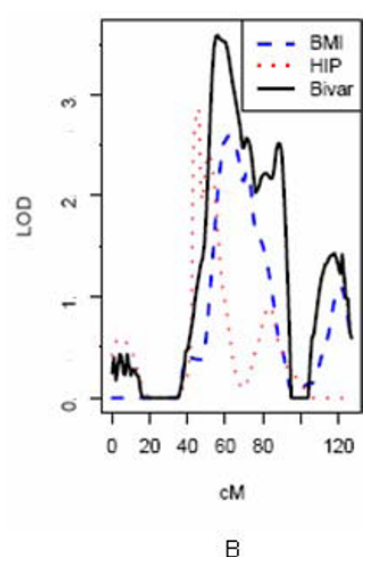

Figure 3 Maximum LOD scores achieved for bivariate linkage to the BMI and hip circumference traits among premenopausal women at chromosome 3 p26 (A) and chromosome 13q13-q14 (B)

mechanisms $[47,48]$. In humans, PPARG activation causes a shift in fat distribution from visceral to subcutaneous fat, increases plasma adiponectin, decreases plasma resistin and suppresses macrophage production of inflammatory markers - all which result in improved insulin sensitivity and glycemic control [43]. Treatment with estrogen prevented intra-abdominal fat deposition $[26,27]$ and promoted fat oxidation in muscle through up-regulation of PPARG expression [49]. If the absence of estrogen leads to abdominal fat deposition, it is possible that reduced PPARG expression may act cooperatively to potentiate metabolic syndrome-related symptoms that are often associated with increased waist girth [44]. HTR2A encodes a serotonin receptor and serotonin is a key mediator in the control of appetite, weight regulation and body weight distribution [50] (also reviewed in [45]). Low cerebrospinal fluid levels of serotonin metabolites have been found in women with primarily abdominal obesity [51]. Furthermore, serotonin responsivity declines after menopause [52], and estrogen treatment in post-menopausal women both decreases brain 5-HT2A receptors [53] and prevents abdominal fat deposition [26,27], possibly by restoring the sensitivity of the receptors to circulating serotonin. Interestingly, estrogen receptor beta (ER $\beta)$ is the receptor responsible for serotonergic neurotransmission in primates [46]. $E S R 2$, which encodes $E R \beta$, is within the marker interval at $14 \mathrm{q} 23$ that linked to hip circumference among postmenopausal women in our study. In addition, our linkage analysis identified novel regions and putative genes that may also be associated with obesity-related phenotypes including PISKB, HAAO, CNTN4, GRM7, UFM1, RB1, $B O D 1 L, S T A R D 4, E G L N 3$ and NRN1. Interestingly, some of these genes appear to play a role in neurological disorders [54], or neuronal development or signaling [55-57], similar to those genes identified recently in the GWAS [12,38].

Although our findings point to plausible genetic influences for obesity traits by menopausal status, this study also has potential limitations. The findings were based on a small sample size with a relatively small number of genetic markers. We reduced the possibility that evidence for linkage was due to a few families with extreme phenotypes by ensuring the phenotypes were normally distributed. Further, the genetic effect on phenotypes such as BMI may decrease with age as one loses height or muscle mass [39]. Ideally, serial measurements would strengthen and serve to validate genetic analyses of quantitative obesity-related phenotypes [58].

\section{Conclusions}

In summary, these results provide a genetic basis for fat deposition that differs by menopausal status, and suggests the same loci encode genes that influence general obesity (BMI) and specifically hip circumference among pre-menopausal women. However, lower heritability among pre-menopausal women for waist circumference and WHR suggests that pre-menopausal waist girth may be influenced to a greater extent by controllable environmental factors than post-menopausal waist girth. Although requiring confirmation, it is possible that targeted interventions among pre-menopausal women may prevent or attenuate post-menopausal abdominal weight deposition. Future studies will need to disentangle the precise mechanism(s) between the loci/genes reported in this investigation with the environment to aid in our understanding of obesity phenotypes among pre-menopausal and post-menopausal women for chronic disease prevention.

\section{Acknowledgements}

This work was supported by NIH grants P01 CA82267 and R01 CA128931. LEK is supported by a Canadian Institutes of Health Research Investigator award. The funding agency had no role in the study design, collection, analysis or interpretation of the data, or in the writing of the manuscript, or in the decision to submit the manuscript for publication.

\section{Author details}

${ }^{1}$ Department of Population Health Research, Alberta Health Services-Cancer Care, Calgary, AB, Canada. ${ }^{2}$ Department of Health Sciences Research, Mayo Clinic College of Medicine, Rochester, MN, USA. ${ }^{3}$ Department of Laboratory Medicine and Pathology, Mayo Clinic College of Medicine, Rochester, MN, USA. ${ }^{4}$ Department of Cancer Epidemiology and Genetics, H. Lee Moffitt Cancer Center and Research Institute, Tampa, FL, USA.

\section{Authors' contributions}

LEK contributed to analysis and interpretation of data, and drafted and revised the manuscript; CMV, TAS and FJC conceived the study design, acquired the data and funding, and contributed to manuscript revisions; EJA, MdA, VSP and AW implemented and interpreted the statistical analysis and contributed to manuscript revisions; JMC and $\mathrm{CAH}$ performed and interpreted the genotyping data; all authors read and approved the final manuscript. 


\section{Competing interests}

The authors declare that they have no competing interests.

Received: 21 July 2010 Accepted: 9 November 2010

Published: 9 November 2010

\section{References}

1. Cancer Trends Progress Report - 2007 Update. [http://progressreport. cancer.gov].

2. Flegal $\mathrm{KM}$, Carroll MD, Ogden $\mathrm{CL}$, Curtin LR: Prevalence and trends in obesity among US adults, 1999-2008. JAMA 2010, 303(3):235-241.

3. Danaei G, Vander Hoorn S, Lopez AD, Murray CJ, Ezzati M: Causes of cancer in the world: comparative risk assessment of nine behavioural and environmental risk factors. Lancet 2005, 366(9499):1784-1793.

4. Bray GA, Bellanger T: Epidemiology, trends, and morbidities of obesity and the metabolic syndrome. Endocrine 2006, 29(1):109-117.

5. Calle EE, Kaaks R: Overweight, obesity and cancer: epidemiological evidence and proposed mechanisms. Nat Rev Cancer 2004, 4(8):579-591.

6. Rankinen T, Zuberi A, Chagnon YC, Weisnagel SJ, Argyropoulos G, Walts B, Perusse L, Bouchard C: The human obesity gene map: the 2005 update. Obesity (Silver Spring, Md) 2006, 14(4):529-644.

7. Herbert A, Gerry NP, McQueen MB, Heid IM, Pfeufer A, Illig T, Wichmann HE, Meitinger T, Hunter D, Hu FB, et al: A common genetic variant is associated with adult and childhood obesity. Science (New York, NY) 2006, 312(5771):279-283

8. Dina C, Meyre D, Gallina S, Durand E, Korner A, Jacobson P, Carlsson LM Kiess W, Vatin V, Lecoeur C, et al: Variation in FTO contributes to childhood obesity and severe adult obesity. Nature genetics 2007. 39(6):724-726.

9. Chambers JC, Elliott P, Zabaneh D, Zhang W, Li Y, Froguel P, Balding D, Scott J, Kooner JS: Common genetic variation near MC4R is associated with waist circumference and insulin resistance. Nature genetics 2008, 40(6):716-718

10. Liu YJ, Liu XG, Wang L, Dina C, Yan H, Liu JF, Levy S, Papasian CJ, Drees BM, Hamilton JJ, et al: Genome-wide association scans identified CTNNBL1 as a novel gene for obesity. Human molecular genetics 2008, 17(12):1803-1813.

11. Benzinou M, Creemers JW, Choquet H, Lobbens S, Dina C, Durand E, Guerardel A, Boutin P, Jouret B, Heude B, et al: Common nonsynonymous variants in PCSK1 confer risk of obesity. Nature genetics 2008, 40(8):943-945

12. Thorleifsson $G$, Walters GB, Gudbjartsson DF, Steinthorsdottir $V$, Sulem $P$, Helgadottir A, Styrkarsdottir U, Gretarsdottir S, Thorlacius S, Jonsdottir I, et al: Genome-wide association yields new sequence variants at seven loci that associate with measures of obesity. Nature genetics 2009, 41(1):18-24.

13. Willer CJ, Speliotes EK, Loos RJ, Li S, Lindgren CM, Heid IM, Berndt SI, Elliott AL, Jackson AU, Lamina C, et al: Six new loci associated with body mass index highlight a neuronal influence on body weight regulation. Nature genetics 2009, 41(1):25-34.

14. Lindgren CM, Heid IM, Randall JC, Lamina C, Steinthorsdottir V, Qi L, Speliotes EK, Thorleifsson G, Willer CJ, Herrera BM, et al: Genome-wide association scan meta-analysis identifies three Loci influencing adiposity and fat distribution. PLoS genetics 2009, 5(6):e1000508.

15. Maes $\mathrm{HH}$, Neale MC, Eaves $\sqcup$ : Genetic and environmental factors in relative body weight and human adiposity. Behavior genetics 1997, 27(4):325-351

16. Atwood LD, Heard-Costa NL, Cupples LA, Jaquish CE, Wilson PW, D'Agostino RB: Genomewide linkage analysis of body mass index across 28 years of the Framingham Heart Study. Am J Hum Genet 2002, 71(5):1044-1050

17. Folsom AR, Kushi LH, Anderson KE, Mink PJ, Olson JE, Hong CP, Sellers TA, Lazovich D, Prineas RJ: Associations of general and abdominal obesity with multiple health outcomes in older women: the lowa Women's Health Study. Arch Intern Med 2000, 160(14):2117-2128.

18. Wajchenberg BL: Subcutaneous and visceral adipose tissue: their relation to the metabolic syndrome. Endocr Rev 2000, 21(6):697-738.

19. Mathieu P, Poirier P, Pibarot P, Lemieux I, Despres JP: Visceral obesity: the link among inflammation, hypertension, and cardiovascular disease. Hypertension 2009, 53(4):577-584.
20. Lissner L, Bjorkelund C, Heitmann BL, Seidell JC, Bengtsson C: Larger hip circumference independently predicts health and longevity in a Swedish female cohort. Obes Res 2001, 9(10):644-646.

21. Seidell JC, Perusse L, Despres JP, Bouchard C: Waist and hip circumferences have independent and opposite effects on cardiovascular disease risk factors: the Quebec Family Study. Am I Clin Nutr 2001, 74(3):315-321.

22. Flegal $\mathrm{KM}$, Carroll MD, Ogden $\mathrm{CL}$, Johnson $\mathrm{CL}$ : Prevalence and trends in obesity among US adults, 1999-2000. Jama 2002, 288(14):1723-1727.

23. Lovejoy JC: The menopause and obesity. Prim Care 2003, 30(2):317-325.

24. Sowers M, Zheng H, Tomey K, Karvonen-Gutierrez C, Jannausch M, Li X, Yosef M, Symons J: Changes in body composition in women over six years at midlife: ovarian and chronological aging. The Journal of clinical endocrinology and metabolism 2007, 92(3):895-901.

25. Guthrie JR, Dennerstein L, Taffe JR, Lehert $P$, Burger HG: The menopausal transition: a 9-year prospective population-based study. The Melbourne Women's Midlife Health Project. Climacteric 2004, 7(4):375-389.

26. Haarbo J, Marslew U, Gotfredsen A, Christiansen C: Postmenopausal hormone replacement therapy prevents central distribution of body fat after menopause. Metabolism: clinical and experimental 1991, 40(12):1323-1326.

27. Mattiasson I, Rendell M, Tornquist C, Jeppsson S, Hulthen UL: Effects of estrogen replacement therapy on abdominal fat compartments as related to glucose and lipid metabolism in early postmenopausal women. Hormone and metabolic research = Hormon-und Stoffwechselforschung = Hormones et metabolisme 2002, 34(10):583-588.

28. Sellers TA, Anderson VE, Potter JD, Bartow SA, Chen PL, Everson L, King RA, Kuni CC, Kushi LH, McGovern PG, et al: Epidemiologic and genetic followup study of 544 Minnesota breast cancer families: design and methods. Genet Epidemiol 1995, 12(4):417-429.

29. Weaver TW, Kushi LH, McGovern PG, Potter JD, Rich SS, King RA, Whitbeck J, Greenstein J, Sellers TA: Validation study of self-reported measures of fat distribution. Int I Obes Relat Metab Disord 1996, 20(7):644-650.

30. Olson JE, Atwood LD, Grabrick DM, Vachon CM, Sellers TA: Evidence for a major gene influence on abdominal fat distribution: the Minnesota Breast Cancer Family Study. Genet Epidemiol 2001, 20(4):458-478.

31. Sobel $E$, Lange $K$ : Descent graphs in pedigree analysis: applications to haplotyping, location scores, and marker-sharing statistics. Am J Hum Genet 1996, 58(6):1323-1337.

32. Lange K, Boehnke M: Extensions to pedigree analysis. IV. Covariance components models for multivariate traits. Am J Med Genet 1983, 14(3):513-524.

33. de Andrade M, Atkinson EJ, Lunde EM, Chen J: Estimating Genetic Components of Variance in Family Studies Using the MULTIC Routines. Technical Report Series No. 78 Rochester, MN: Dept of Health Science Research, Mayo Clinic; 2006.

34. de Andrade M, Thiel TJ, Yu L, Amos Cl: Assessing linkage on chromosome 5 using components of variance approach: univariate versus multivariate. Genetic Epidemiology 1997, 14(6):773-778.

35. Thomas DC: Statistical Methods in Genetic Epidemiology. Oxford: Oxford University Press; 2004.

36. Lander $E$, Kruglyak L: Genetic dissection of complex traits: guidelines for interpreting and reporting linkage results. Nat Genet 1995, 11(3):241-247.

37. Iturria SJ, Blangero J: An EM algorithm for obtaining maximum likelihood estimates in the multi-phenotype variance components linkage model. Ann Hum Genet 2000, 64(Pt 4):349-362.

38. Heard-Costa NL, Zillikens MC, Monda KL, Johansson A, Harris TB, Fu M, Haritunians T, Feitosa MF, Aspelund T, Eiriksdottir G, et al: NRXN3 is a novel locus for waist circumference: a genome-wide association study from the CHARGE Consortium. PLoS Genet 2009, 5(6):e1000539.

39. Samaras K, Spector TD, Nguyen TV, Baan K, Campbell LV, Kelly PJ: Independent genetic factors determine the amount and distribution of fat in women after the menopause. J Clin Endocrinol Metab 1997, 82(3):781-785.

40. Eichler EE, Flint J, Gibson G, Kong A, Leal SM, Moore JH, Nadeau JH: Missing heritability and strategies for finding the underlying causes of complex disease. Nat Rev Genet 2010, 11(6):446-450.

41. Visscher PM, Hill WG, Wray NR: Heritability in the genomics era-concepts and misconceptions. Nat Rev Genet 2008, 9(4):255-266. 
42. Sowers MR, Wildman RP, Mancuso P, Eyvazzadeh AD, KarvonenGutierrez CA, Rillamas-Sun E, Jannausch ML: Change in adipocytokines and ghrelin with menopause. Maturitas 2008, 59(2):149-157.

43. Sharma AM, Staels B: Review: Peroxisome proliferator-activated receptor gamma and adipose tissue-understanding obesity-related changes in regulation of lipid and glucose metabolism. The Journal of clinical endocrinology and metabolism 2007, 92(2):386-395.

44. Carr MC: The emergence of the metabolic syndrome with menopause. The Journal of clinical endocrinology and metabolism 2003, 88(6):2404-2411.

45. Erritzoe D, Frokjaer VG, Haugbol S, Marner L, Svarer C, Holst K, Baare WF, Rasmussen PM, Madsen J, Paulson OB, et al: Brain serotonin 2A receptor binding: relations to body mass index, tobacco and alcohol use. Neurolmage 2009, 46(1):23-30.

46. Gundlah C, Lu NZ, Mirkes SJ, Bethea CL: Estrogen receptor beta (ERbeta) mRNA and protein in serotonin neurons of macaques. Brain research 2001, 91(1-2):14-22.

47. Nahon JL: The melanocortins and melanin-concentrating hormone in the central regulation of feeding behavior and energy homeostasis. C $R$ Biol 2006, 329(8):623-638, discussion 653-625.

48. Perez-Tilve D, Nogueiras R, Mallo F, Benoit SC, Tschoep M: Gut hormones ghrelin, PYY, and GLP-1 in the regulation of energy balance [corrected] and metabolism. Endocrine 2006, 29(1):61-71.

49. D'Eon TM, Souza SC, Aronovitz M, Obin MS, Fried SK, Greenberg AS: Estrogen regulation of adiposity and fuel partitioning. Evidence of genomic and non-genomic regulation of lipogenic and oxidative pathways. The Journal of biological chemistry 2005, 280(43):35983-35991.

50. Leibowitz SF: The role of serotonin in eating disorders. Drugs 1990, 39(Suppl 3):33-48.

51. Bjorntorp P: Neuroendocrine abnormalities in human obesity. Metabolism: clinical and experimental 1995, 44(2 Suppl 2):38-41.

52. Halbreich U, Rojansky N, Palter S, Tworek H, Hissin P, Wang K: Estrogen augments serotonergic activity in postmenopausal women. Biological psychiatry 1995, 37(7):434-441.

53. Compton J, Travis MJ, Norbury R, Erlandsson K, van Amelsvoort T, Daly E, Waddington W, Matthiasson P, Eersels JL, Whitehead M, et al: Long-term estrogen therapy and $5-\mathrm{HT}(2 \mathrm{~A})$ receptor binding in postmenopausal women; a single photon emission tomography (SPET) study. Hormones and behavior 2008, 53(1):61-68.

54. Roohi J, Montagna C, Tegay DH, Palmer LE, DeVincent C, Pomeroy JC, Christian SL, Nowak N, Hatchwell E: Disruption of contactin 4 in three subjects with autism spectrum disorder. Journal of medical genetics 2009, 46(3):176-182.

55. Ruddick JP, Evans AK, Nutt DJ, Lightman SL, Rook GA, Lowry CA: Tryptophan metabolism in the central nervous system: medical implications. Expert reviews in molecular medicine 2006, 8(20):1-27.

56. Niswender CM, Conn PJ: Metabotropic glutamate receptors: physiology, pharmacology, and disease. Annual review of pharmacology and toxicology 50:295-322.

57. Naeve GS, Ramakrishnan M, Kramer R, Hevroni D, Citri Y, Theill LE: Neuritin: a gene induced by neural activity and neurotrophins that promotes neuritogenesis. Proceedings of the National Academy of Sciences of the United States of America 1997, 94(6):2648-2653.

58. Pollex RL, Hegele RA: Longitudinal differences in familial combined hyperlipidemia quantitative trait loci. Arterioscler Thromb Vasc Biol 2006, 26(6):e120.

\section{Pre-publication history}

The pre-publication history for this paper can be accessed here: http://www.biomedcentral.com/1471-2350/11/156/prepub

doi:10.1186/1471-2350-11-156

Cite this article as: Kelemen et al:: Linkage analysis of obesity

phenotypes in pre- and post-menopausal women from a United States mid-western population. BMC Medical Genetics 2010 11:156.

\section{Submit your next manuscript to BioMed Central and take full advantage of:}

- Convenient online submission

- Thorough peer review

- No space constraints or color figure charges

- Immediate publication on acceptance

- Inclusion in PubMed, CAS, Scopus and Google Scholar

- Research which is freely available for redistribution

Submit your manuscript at www.biomedcentral.com/submit
C Biomed Central 